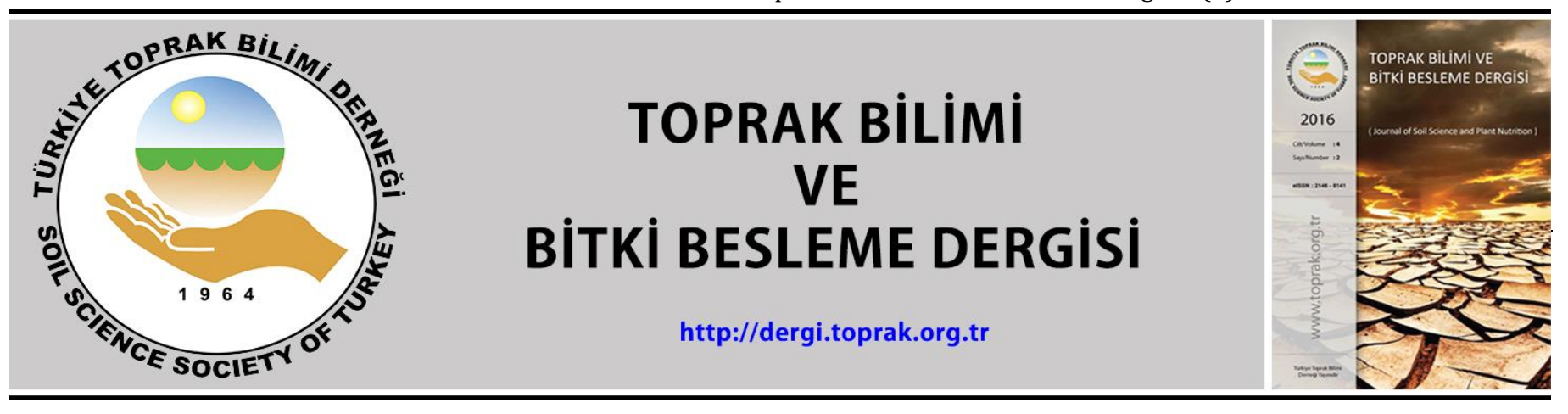

\title{
Farklı yetiştirme ortamlarında bazı bakterilerin buğday ve mısır gelişimi üzerine etkisi \#
}

\author{
Banu Kadıŏlu *, Mustafa Y. Canbolat
}

Atatürk Üniversitesi, Ziraat Fakültesi, Toprak Bilimi ve Bitki Besleme Bölümü, Erzurum

\section{Özet}

Araştırma, farklı ortamlarda bitki büyümesini teşvik edici rizobakterilerinin (PGPR) buğday ve mısır bitkisi gelişimindeki etkilerini belirlemek amacı ile yapılmıștır. Yetiștirme ortamı olarak ağırlık esasına göre \% 100 pomza, perlit, torf, toprak ve farklı oranlardan olușturulan karışımları kullanılmıștır. Azot bağlayıcı ve fosfor çözücü bakterilerle (P. aglomerans, P. putida, B. suptilis ve A. agilis) aşılanan mısır ve buğdayların kök ve gövde gelişimleri izlenmiş ve bazı ölçümler alınmıştır. Araştırma sonuçlarına göre; \%100 pomzadan oluşan ortamda bitkilerin kuru kök ve gövde ağırlı̆̆ $\% 100$ torfda ise bakteri sayısı artmıștır. Materyal/ toprak karışımlarında toprak oranı arttığı zaman kuru kök ve gövde ağırlığının ve bitkilerde azot, fosfor ve potasyum içeriğinin arttığı, bakteri sayısının ise azaldığı tespit edilmiștir. Bakterilerden P.aglomerans ve A.agilis suşlarının daha etkin olduğu belirlenmiștir. Anahtar Kelimeler: Bitki besin elementleri, buğday, mısır, PGPR, ortam.

\section{The effect of some bacteria on wheat and corn growth in different growing environments} \begin{abstract}
The aim of this study was to determine the effects of plant growth-promoting rhizobacterias (PGPR) on wheat and maize plant growth. In the study, $100 \%$ pumice, perlite, peat, soil and mixtures formed from different ratios were used as a growth media. Root and stem growths of corn and wheat were inoculated with nitrogen binding and phosphorus solvent bacteria (P. aglomerans, P. putida, B. suptilis and A. agilis) and some measurements were taken. According to the research results; when $100 \%$ pumice material increases dry root and stem weight and $100 \%$ peat material increases the number of bacteria. When the soil amount increased in the substrate/soil mixtures, dry root and stem weight and plant nitrogen, phosphorus and potassium content increased and the number of bacteria decreased. P. aglomerans and A.agilis strains were found to be more effective.

Keywords: Plant nutrients, wheat, corn, PGPR, growth media
\end{abstract}

(C) 2019 Türkiye Toprak Bilimi Derneği. Her Hakkı Saklıdır

\section{Giriş}

Günümüzün en önemli konularından biri kaliteli ve güvenli gıda için toprak varlığının ve özelikle de toprak sağlığının korunmasıdır. Bu da ancak sürdürülebilir tarım sistemi ile mümkün olabilecektir. Sürdürülebilir tarım sistemi ile organik artıkların geri kazandırılması, biyolojik gübrelerle toprağın güçlendirilmesi, biyolojik mücadele metotları ve tarım ekosistemlerini kirleticilerin biyolojik yollarla temizlenmesi gibi birçok faaliyetin entegrasyonu sağlanmaktadır. Ekolojik bir çevre ve üretim için gerekli bir sistemdir. Tarımsal ekosistemlerde birçok toksik ve tehlikeli kimyasal madde girdileri kullanılmakta ve bunlar bitki, toprak, yer altı ve yerüstü suları ile taşınarak gıdaların içine karışmaktadır. Toprak ortamında bitki gelişimi için ideal koşulları sağlamak amacıyla toprağın fiziksel ve kimyasal özelliklerini düzenleyici olarak pomza, perlit, volkan külü gibi inorganik materyallerle birlikte torf, turba, talaş gibi organik materyaller ayrı ayrı veya karışımlar halinde bitki yetiştirme ortamı olarak doğrudan veya dolaylı olarak kullanılabilmektedir. Türkiye'de 38 milyon hektar tarım arazisinin \%61'ini işlenen tarım arazi oluşturmaktadır (TÜíK, 2019). Yıllar itibari ile giderek azalan bu alanlarda verimi artırmanın ve toprağı korumanın yolu toprağın fiziksel özelliklerini geliştirici materyallerin toprağa uygulanması ve sağlıklı yetiştirme ortamlarının hazırlanmasıdır. Sera şartlarında perlit, pomza ve

\footnotetext{
* Sorumlu yazar:

\# Bu makale, "Pomza perlit ve torf materyallerinin toprakla karıștırılmasından hazırlanan ortamların hidrofiziksel özellikleri ve bu ortamlarda farklı bakterilerle aşılanmış bitkilerin gelişimi" başlıklı doktora tezinden hazırlanmıştır.

Tel_ $\quad 05352501807$

E-posta : banu250@hotmail.com

Geliş Tarihi

Kabul Tarihi

26 Ağustos 2019

25 Kasım 2019

e-ISSN

DOI

2146-8141

$10.33409 /$ tbbbd.668895
} 
toprağın farklı oranlarda karıştırılması ile oluşturulan ortamlarda perlit ve pomza gibi toprak düzenleyicilerinin bitkinin verim ve verim unsurları üzerine olumlu etkisi olduğu (Göçmen, 2005) yine değişik organik (torf) ve inorganik (perlit, volkanik tüf) substratların ve bunların değişik kombinasyonlarının oluşturduğu ortamlarda en yüksek toplam verimin volkanik tüf+torf ortamında olduğu bunu sirasıyla perlit+torf, torf, perlit ve volkanik tüf ortamlarının izlediği, yerli substrat malzemelerinin verim, kalite ve bitki besin elementi dağılımı bakımından avantajlı olduğu ifade edilmiştir (Beşiroğlu, 2007).

Tarımsal üretimde kalite ve verimi artırmak amacıyla kullanılan kimyasalların oluşturabileceği tehditleri önlemek amacı ile sunulan alternatif çözümler arasında "Organik Tarım", "Entegre Mücadele", "İyi Tarım Uygulamaları" gibi kimyasal kullanımını azaltmayı amaçlayan uygulamalardan biriside son yıllarda bitki büyümesini teșvik edici bakterilerin (PGPR) kullanımı olmuştur. PGPR'lar bitkinin büyümesine olumlu katkılar sağlanmaktadır. PGPR bakterileri ile yapılan bir çalışmada, bazı bakterilerin buğdayda gövde ağırlığını artırdığı, en yüksek kök ve gövde ağırlı̆̆ının $P$. polymyxa uygulaması ile elde edildiği bunu $P$. putida ve B. Megaterium'un izlediği belirlenmiștir (Cakmakci ve ark., 2007).

Mikroorganizma populasyonu ile topraktaki fiziksel ve kimyasal aktiviteler gerçekleşmektedir. Toprakta yaşayan mikroorganizmaların büyük bir kısmını oluşturan bakterilere ilişkin çalışmalar da giderek artmaktadır. Yapılan bu çalışma ile farklı yetiştirme ortamlarında farklı PGPR bakterilerinin buğday ve mısır bitkilerinin kök ve gövde gelişimi üzerine etkileri incelenmiștir.

\section{Materyal ve Yöntem}

Araştırmada kontrol olarak toprak materyali kullanılmış ve diğer materyallerin saf halleri ile karışımlarının oluşturduğu on üç (\% 100 Pomza, \% 100 Perlit, \% 100 Torf, \% 100 Toprak, \%75 + \%25 Pomza + Toprak, $\% 75+\% 25$ Perlit + Toprak, \%75 + \%25 Torf + Toprak, \%50 + \%50 Pomza + Toprak, \%50 + \%50 Perlit + Toprak, $\% 50+\% 50$ Torf + Toprak, $\% 25+\% 75$ Pomza + Toprak, $\% 25+\% 75$ Perlit + Toprak, \%25 + \%75 Torf + Toprak) farklı yetiştirme ortamı hazırlanmıştır. Azot bağlayıcı ve fosfor çözücü kabiliyetinde olan Pantoe agglomerans, Pseudomanas putida, Basillus suptilis ve Arthrobacter agilis bakterileri olmak üzere dört farklı PGPR bakterisi kullanılmıștır.

Deneme, Atatürk Üniversitesi Ziraat Fakültesi Toprak Bölümü laboratuvarında üç tekerrürlü olarak tam şansa bağlı tesadüf parselleri deneme desenine göre düzenlenmiştir. Mısır ve buğday tohumları hazırlanan bakteriyal așılama materyali ile așılanmıștır. Her saksıya beș bitki olacak şekilde bitkiler ekilmiș ve kırk gün sonra hasat edilmiştir. Hasat edilen bitkilerin kök ve gövde kısımları $65^{\circ} \mathrm{C}$ 'de sabit ağırlı̆a ulaşıncaya kadar kurutma firınında kurutulmuş kurutulan bitkilerin kök ve gövde kuru ağırlıkları belirlenmiștir. Mikserde ögütüldükten sonra azot (AOAC, 1990), fosfor ve potasyum içerikleri tayin edilmiştir (Mertens, 2005). Toprakların toplam bakteri sayısı dilüsyon-plak metoduyla yapılmıștır (Clark, 1965; Wollum, 1982). Pomza, perlit ve torf materyalleri ile toprağın reaksiyonu 1 (örnek):2,5 (su) oranında hazırlanan süspansiyonlarda potansiyometrik olarak cam elektrotlu pH metre ile saptanmıştır (Mc Lean, 1982). Araştırma sonuçları varyans analizi ve Duncan çoklu karşılaştırma testi (\%5) ile istatiksel olarak test edilmiştir (Dowdy and Wearden, 1983).

\section{Bulgular ve Tartışma}

\section{Kök ve Gövde Kuru Ağırlı̆̆ı}

Bitkiler gelişmeleri için gerekli olan besin elementlerinin büyük çoğunluğunu kökleri vasıtası ile ve az bir kısmını da gövde, dal ve yaprakları vasıtası ile aldıkları için bitkilerde kök sistemleri oldukça önemlidir. Kök sistemleri bitkilerin yetiştikleri ortam koşullarının etkisi altında, yapı, ağırlık, gelişme ve yayılma yönünden farklılık göstermektedir. Kök sistemi denildiği zaman köklerin tümü akla gelmektedir. Su ve besin elementi alımında, bitki kök sistemlerinde kök ucu yaşamsal öneme sahip olmaktadır (Kacar, 1996; Kadığlu ve Canbolat, 2018).

İstatistiki olarak kök ve gövde kuru ağırlığı bakımından denemede kullanılan buğday ve mısır bitkisi birbirlerinden farklı bulunmuştur ( $\mathrm{p}<0.01)$. Kök ve gövde kuru ağırlı̆̆ı sırası ile buğdayda 0.16-0.33 g/saksı mısırda ise 0.41-0.62 g/saksı olarak belirlenmiştir. Buğday bitkisinde kök kuru ağırlığının $0.16 \mathrm{~g} / \mathrm{saksl}$, ve gövde kuru ağırlığının $0.33 \mathrm{~g} / \mathrm{saksı} \mathrm{mısır} \mathrm{bitkisinde} \mathrm{ise} \mathrm{bu} \mathrm{ağırlıkların} 0.41 \mathrm{~g} / \mathrm{saksı} \mathrm{ve} 0.62 \mathrm{~g} / \mathrm{saksı} \mathrm{olduğu}$ belirlenmiştir.

Ortamlar kök kuru ağırlığı bakımından \%5 düzeyinde, gövde kuru ağırlığı bakımından \%1 düzeyinde önemli bulunmuştur. Kök kuru ağırlıkları ortalama değerleri, pomza:toprak ortamında $0.30 \mathrm{~g} / \mathrm{saksı}$ ve torf:toprak ortamında $0.27 \mathrm{~g} / \mathrm{saksı}$ olup iki farklı grupta yer alırken perlit toprak ortamı $0.28 \mathrm{~g}$ la bu iki ortam arasında yer almıştır. Gövde kuru ağırlığı bakımından pomza $0.50 \mathrm{~g} / \mathrm{saksı} \mathrm{ve} \mathrm{perlit} 0.48 \mathrm{~g} / \mathrm{saksı}$ ağırlıklarla aynı 
grupta yer alırken, torf $0.45 \mathrm{~g} /$ saksı gövde kuru ağırlı̆̆ ile farklı bir grup oluşturmuştur. Yapılan benzer çalışmalarda; arpa bitkisinin, yetiştirme ortamı olarak toprak, perlit, pomza, zeolit ile bunların karıșımlarının kullanılmıș, en uygun yetiştirme ortamının pomza olduğu, perlit ortamında ise pomzaya göre daha düşük değerler elde edildiği vurgulanmıştır (Türk ve ark., 2003). Gövde kuru ağırlığı bakımından pomza ve perlit ortamlarında yetiştirilen bitkilerin torf ortamında yetiştirilenlerden daha büyük bir değere sahip olduğu, kök kuru ağırlığı bakımından da perlit ve torf ortamlarına göre pomzanın bu ortamlara göre daha fazla farklılık gösterdiği, toprağa karşılaştırılan pomzanın, bitki su tüketimini azalttığı, bitki kök ve gövde kuru ağırlığı üzerinde artırıcı etkiye sahip olduğu kaydedilmiştir (Karaman, 1993).

Yetiştirme ortamlarına ait materyal karışım oranları gövde ve kök kuru ağırlık değerlerini önemli derecede etkilemiş ve bu etki ortalama değerler bakımından birbirlerinden farklı bulunmuştur. Kök ve gövde kuru ağırlıklarındaki artış, karışım oranları içerisindeki toprak miktarının artışı yönünde bir paralellik göstermiştir.

Bakteri uygulaması gövde ve kök kuru ağırlı̆̆ını önemli derecede etkilemiştir. Kök kuru ağırlığı ortalama değerleri bakımından, kontrol ile bakteri uygulamaları arasında önemli bir farkın olduğu, P. putida'nın en yüksek ortalama değeri $(0.33 \mathrm{~g} / \mathrm{saksı})$ verdiği bunu sırasıyla A. agilis ( $0.30 \mathrm{~g} / \mathrm{saksı}), \mathrm{P}$. aglomerans $(0.29$ $\mathrm{g} / \mathrm{saksı})$ ve B. suptilis ( $0.28 \mathrm{~g} / \mathrm{saksı})$ 'in izlediği belirlenmiştir. Gövde kuru ağırlı̆̆ bakımından kontrol ile bakteri uygulamaları arasında önemli bir farkın olduğu ancak bakteri uygulamaları arasında bir farklılığın olmadığı görülmüştür (Şekil 1).
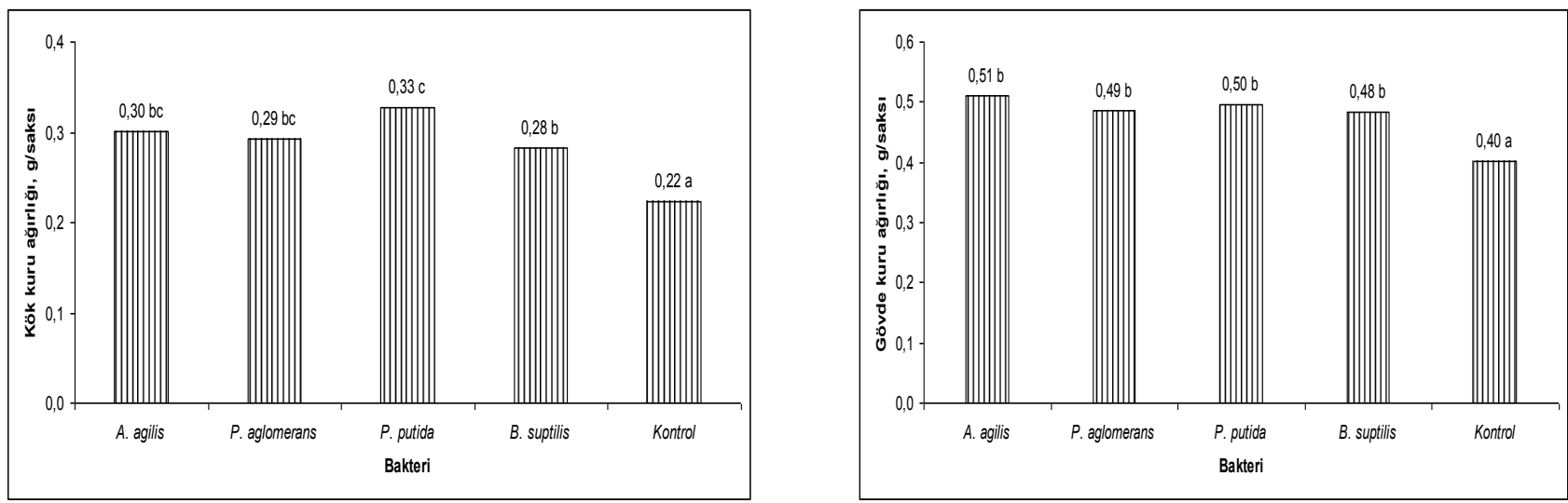

Şekil 1. Farklı bakterilerle aşılanmış buğday ve mısır bitkilerinin kök ve gövde kuru ağırlığı

Buğday bitkisinin gövde kuru ağırlık değerleri, yetiştirme ortamları bakımından birbirinden farksız bulunurken mısır bitkisi için gövde kuru ağırlık değerleri torfun yer aldığı yetiştirme ortamlarında diğer ortamlardan farklı bulunmuştur. Buğday ve mısır bitkisi kök ve gövde kuru ağırlığı, karışım oranlarında toprak içeriğinin artışına bağlı olarak artış göstermiştir. Bu artış oranları, mısır bitkisinde daha belirgin olup buğday bitkisinde düşük seyretmiştir.

Karışım oranının 100:0 olduğu örneklerde en yüksek gövde kuru ağırlığını $0.34 \mathrm{~g} / \mathrm{saksı} \mathrm{değeri} \mathrm{ile} \mathrm{pomza}$ ortamı sağlarken $0.20 \mathrm{~g} / \mathrm{saksı}$ değeri ile torf en düșük değere sahip olmuștur. Benzer durum, 25:75 karıșım oranının olduğu örneklerde de elde edilmiş olup, en yüksek gövde kuru ağırlığını $0.70 \mathrm{~g} / \mathrm{saksı} \mathrm{değeri} \mathrm{ile}$ pomza ortamı sağlarken $0.59 \mathrm{~g} /$ saksı değeri ile torf en düşük değere sahip olmuştur. Sadece toprağın yer aldığı kontrol örneğinde gövde kuru ağırlığı 0.73 g/saksı değeri ile üç farklı materyalin yer aldığı karışım değerlerinden daha yüksek gövde kuru ağırlığının ortaya çıkmasını sağlamıştır (Şekil 2).

Buğday bitkisi kök kuru ağırlıkları üzerine bakteri uygulamasının istatistiksel olarak önemli olmadığı, ancak bulunan ortalama değerler bakımından en düşük değerin $(0.14 \mathrm{~g} / \mathrm{saksı})$ kontrol örneğinde ortaya çıktığı kaydedilmiştir. Mısır bitkisinde ise kök kuru ağırlığı kontrol örneğinde $0.30 \mathrm{~g} / \mathrm{saksı} \mathrm{olup} \mathrm{bakteri}$ uygulamasının olduğu örneklerden daha düşük bir değeri göstermiş̧tir. En yüksek değeri $0.49 \mathrm{~g} / \mathrm{saksı} \mathrm{ile} \mathrm{P.}$ putida bakteri uygulaması verirken bunu A. agilis, P. aglomerans ve B. suptilis izlemiştir (Şekil 3).

Buğday bitkisi gövde kuru ağırlıkları üzerinde de bakteri uygulamasının istatistiksel olarak önemli olmadığı, ancak bulunan ortalama değerler bakımından en düşük değerin $(0.31 \mathrm{~g} / \mathrm{saksı})$ kontrol örneğinde ortaya çıktığı kaydedilmiştir. Mısır bitkisinde ise kök kuru ağırlığı kontrol örneğinde $0.49 \mathrm{~g} / \mathrm{saksı}$ olup bakteri uygulamasının olduğu örneklerden daha düşük bir değeri göstermiştir. En yüksek değeri $0.68 \mathrm{~g} / \mathrm{saksı} \mathrm{ile} \mathrm{A.}$ agilis bakteri uygulaması verirken bunu, P. aglomerans, P.putida ve B. suptilis izlemiştir (Şekil 3). PGPR'lar hızlı kök oluşumu, lateral ve kılcal köklerin gelişimi, kök ve çevresinden su ve besin alımı ve kök canlılığının artırılmasında özellikle genç bitkiler için önemli olabilmektedir (Cakmakci ve ark., 2006; Shakir ve ark., 2012; Bangash ve ark., 2013). 


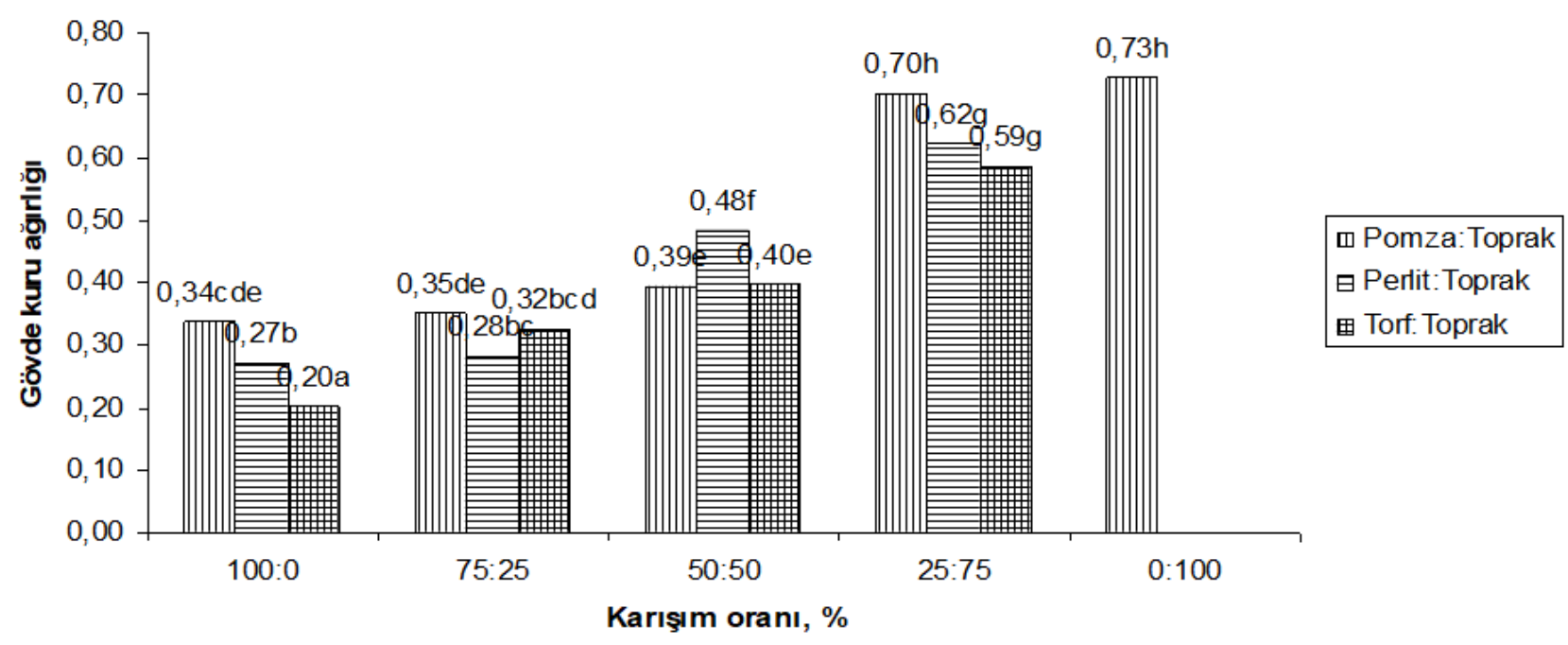

Şekil 2. Farklı ortam ve toprak karışım oranlarında yetiştirilen buğday ve mısır bitkilerinin gövde kuru ağırlı̆̆ı
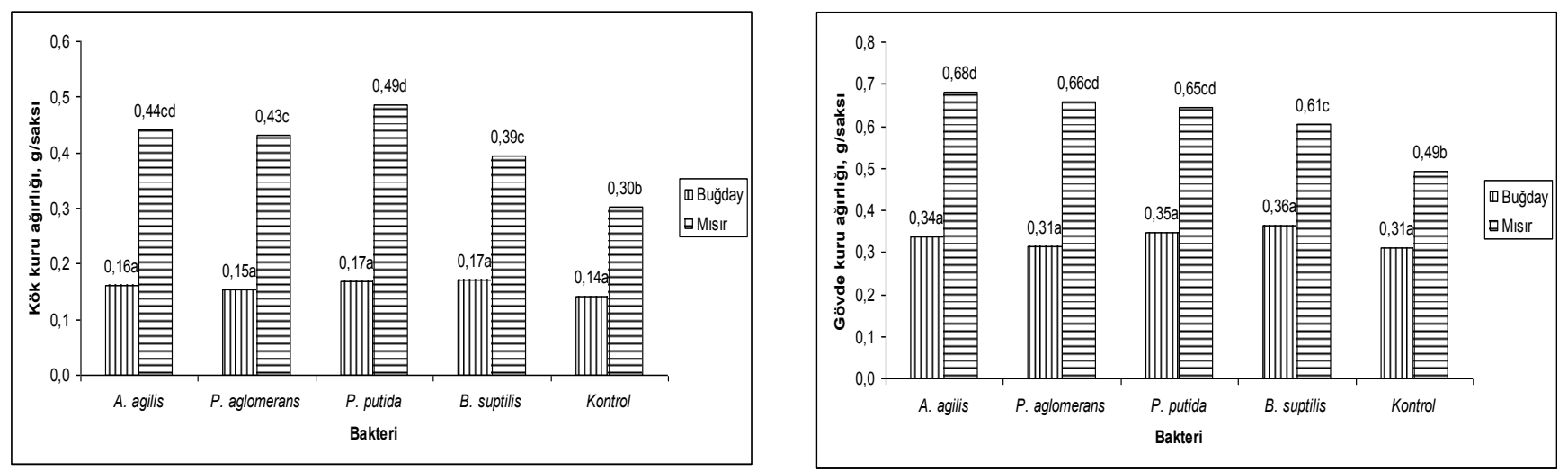

Şekil 3. Farklı bakterilerle aşılanmış buğday ve mısır bitkilerinin kök ve gövde kuru ağırlı̆̆

Buğdayda PGPR uygulamasının gövde ağırlığını artırdığı, en yüksek kök ve gövde ağırlığını P. polymyxa' nın sağladığı bunu P. putida, B. megaterium ve P. polymyxa'nın izlediği kaydedilmiştir. PGPR'ın buğdayda kök ve gövde artırdığı saptanmıştır. Kök ve gövde ağırlığında artışlar sağladığı farklı çalışmalarda da belirlenmiştir (Cakmakci ve ark., 2007; Baset Mia ve ark., 2010; Bangash ve ark., 2013). Pseudomonas bakterilerinden özellikle P. fluorescens ve P. putida'nın birçok bitkinin gelişimini teşvik ederek önemli oranda bitki verimini artırdığı da bulunmuştur (Kloepper ve ark., 1989; Vessey, 2003).

Gövde kuru ağırlığı bakımından ortam ve bakteri interaksiyonu önemli bulunmuştur. Pomzanın yer aldığı ortamlarda P. aglomerans, P. putida ve B. suptilis uygulamaları gövde kuru ağırlığı bakımından perlit ve torfa göre daha yüksek değerler vermiştir. A. agilis uygulamasında perlit ortamında pomza ve torfa göre daha yüksek gövde kuru ağırlığı değerleri elde edilmiștir (Şekil 4).

Bakteri ve ortam arasındaki interaksiyon hem gövde hem de kök kuru ağırlığı için önemli bulunmuştur. Genel olarak toprak içeriğinin artmasına bağlı olarak bakteri uygulamasının etkinliği kök ve gövde kuru ağırlığının artışı üzerinde etkili olmuştur. Bakteri uygulamasında kontrol örneklerinin kök ve gövde kuru ağırlığı değerleri 100:0 karışım oranı hariç uygulamalardan daha düşük bulunmuştur (Şekil 5).

Yapılan benzer çalışmalarda bitki gelişimi üzerine mikroorganizmaların etkinliğinin farklı olduğu, özellikle Azotobacter ve Azospirillum türlerinin üretim artışlarında etkinliğinin yüksek olduğu (Çakmakçı, 2005a). İnokulant özelliklerine ve kullanılan tahıl türüne bağlı olarak serbest azot bağlayıcılarının \%20-50 oranında verim artışı sağladığı (Jagnow, 1987) buğdayda \%11 mısırda \%12.5 verim artışı sağladığı (Chen ve ark., 1996) kaydedilmiştir.

Tohumlara ya da toprağa PGPR uygulamasının kök gelişimi, besin elementi alımı, azot fiksasyonu, inorganik fosfat çözünürlügü ve alımını artırdığı vurgulanmıştır (Lucy ve ark., 2004; Sahin ve ark., 2004; Çakmakçı, 2005b; Canbolat ve ark., 2006). 


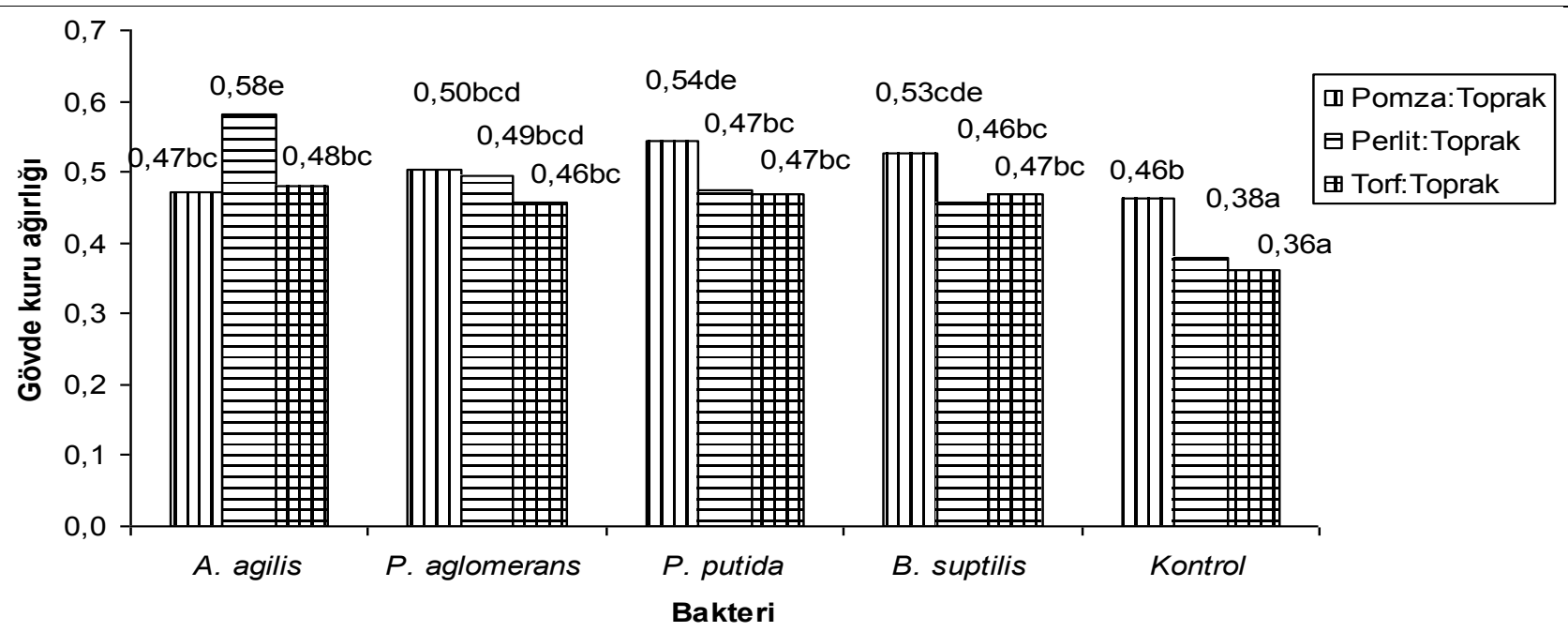

Şekil 4. Farklı bakterilerle aşılanmış buğday ve mısır bitkilerinin üç farklı ortamdaki gövde kuru ağırlığı
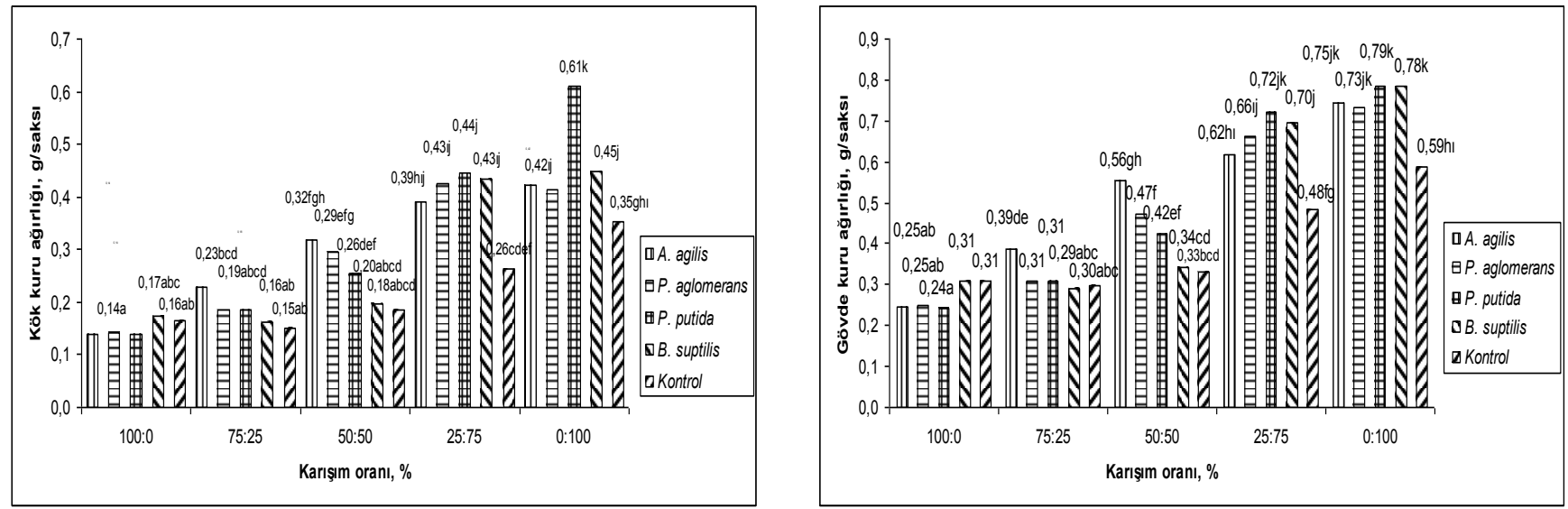

Şekil 5. Farklı bakterilerin ortam ve toprak karışım oranlarına göre kök ve gövde kuru ağırlığı

\section{Bitki Azot İçeriği}

Bakteri uygulaması bitki azot içeriğinde oldukça farklılık sergilemiştir. Ortalama bitki azot içeriği kontrol grubunda (a) \%1.79, B. suptilis bakterisinin yer aldığı ikinci grupta (b) \%1.89, A.agilis ve P.aglomerans bakterilerinin yer aldığı üçüncü grupta (c) \%1.94 ile \%1.93 ve P. putida bakterisinin yer aldığı dördüncü grupta (d) \%1.95 olarak bulunmuştur.

Bitki azot içeriği bakımından ortam ve bakteri uygulaması ile farklı sonuçlar elde edilmiştir. Pomza:toprak ortamı için bakteriler iki grup içerisinde yer almıştır. Bakterilerden, A. agilis, P. aglomerans ve P. putida'nın bulunduğu örneklerdeki bitki azot içeriği değerleri sırası ile \%1,89, \%1.86 ve \%1.88 olup bir grupta, B. suptilis bakterisinin bulunduğu örnekteki bitki azot içeriği değeri de \%1.81 olup diğer grupta yer almıștır. Pomza için kontrol grubu bitki azot içeriği değeri \%1.68 olarak bulunmuştur. Perlit:toprak ortamında P. putida ve B. suptilis bakterilerinin bulunduğu örneklerde bitki azot içeriği değerleri \%2.07 ve \%2.05 olup bir grup içerisinde yer alırken bunları, A. agilis (\%1.96), P. aglomerans (\%1.92) izlemiştir. Perlit için kontrol grubu bitki azot içeriği değeri \%1.87 olarak kaydedilmiştir. Torf:toprak ortamında, P. aglomerans bakterisinin bulunduğu örneklerde bitki azot içeriği \%2 olup bunu A. agilis (\%1.96), P. putida (\%1.91) ve B. suptilis (\%1.83) izlemiştir. Kontrol grubu bitki azot içeriği değeri B. suptilis bakterisinin sağladığı bitki azot içeriği değeri ile aynı grupta yer almıştır (Şekil 6). Azot oranının artmasına makro ve mikro organizmaların, organik maddenin ve su miktarındaki artışın neden olması torf ortamında ve kontrol oranında azot miktarının artmasına yol açmıştır. Nitekim benzer sonuçlar farklı araştırıcılar tarafından da elde edilmiştir (Garten ve Van Miegroet, 1994; Knoepp and Swank, 1998; Ping and Boland, 2004). 


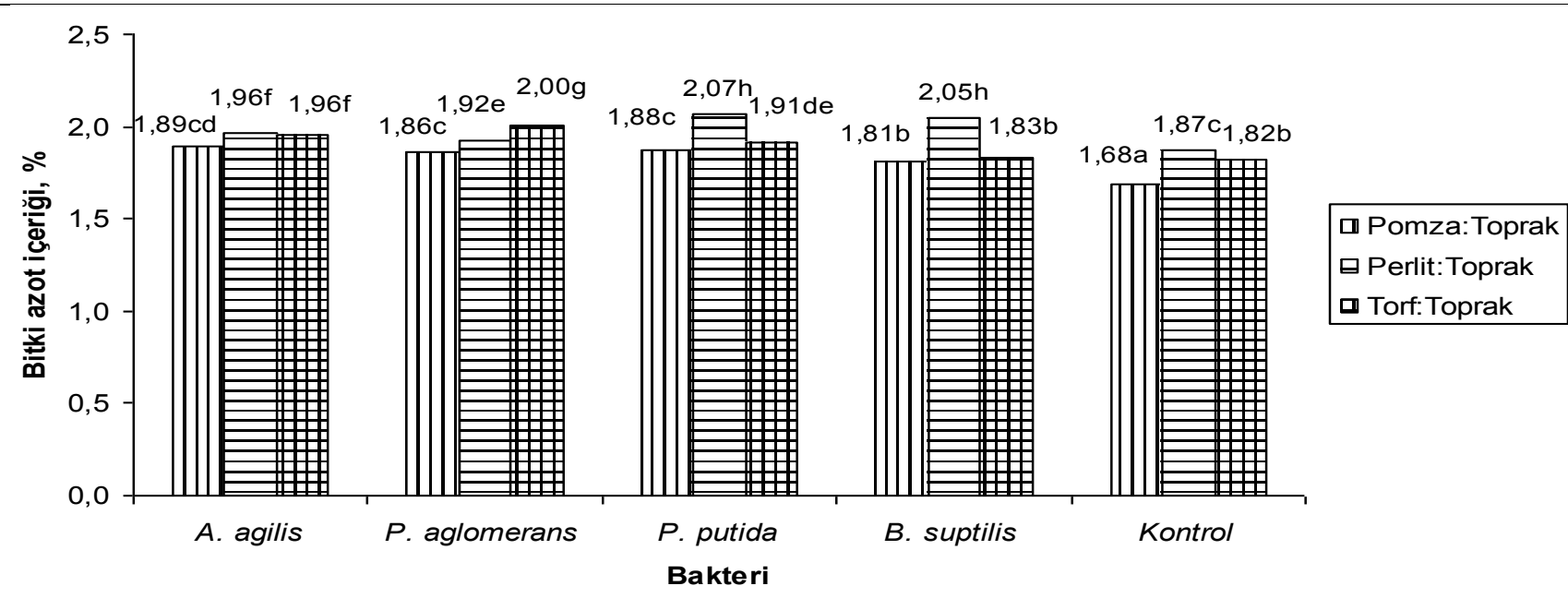

Şekil 6. Farklı bakterilerle aşılanmış buğday ve mısır bitkilerinin üç farklı ortamdaki bitki azot içeriği

\section{Bitki Fosfor İçeriği}

Toprakta besin elementleri dengesinin sağlanmasının, toprak özelliklerinin düzeltilmesinin, toprak verimliliği ve bitkisel üretim açısından önemli olduğu ve bitki gelişimi için 16 bitki besin elementinin vazgeçilmez olduğu bilinmektedir. 16 bitki besin elementinden N,P,K halk tarafından dal, döl ve bal olarak bilinen gübrelemede en çok kullanılan besin elementleridir. Araştırmada kullanılan buğday ve mısır bitkilerinin fosfor içeriği ile ilgili varyans analiz sonuçlarına göre ortam, bakteri sayısı ve interaksiyonlarının \%1'de önemli olduğu bulunmuştur. Denemede P.aglomerans ve P. putida ile așlanmıș bitkilerin fosfor içeriğinin diğer iki bakteri grubundan daha yüksek olduğu kontrol grubunun ise en düşük bitki fosfor içeriğini verdiği görülmüştür (Şekil 7).

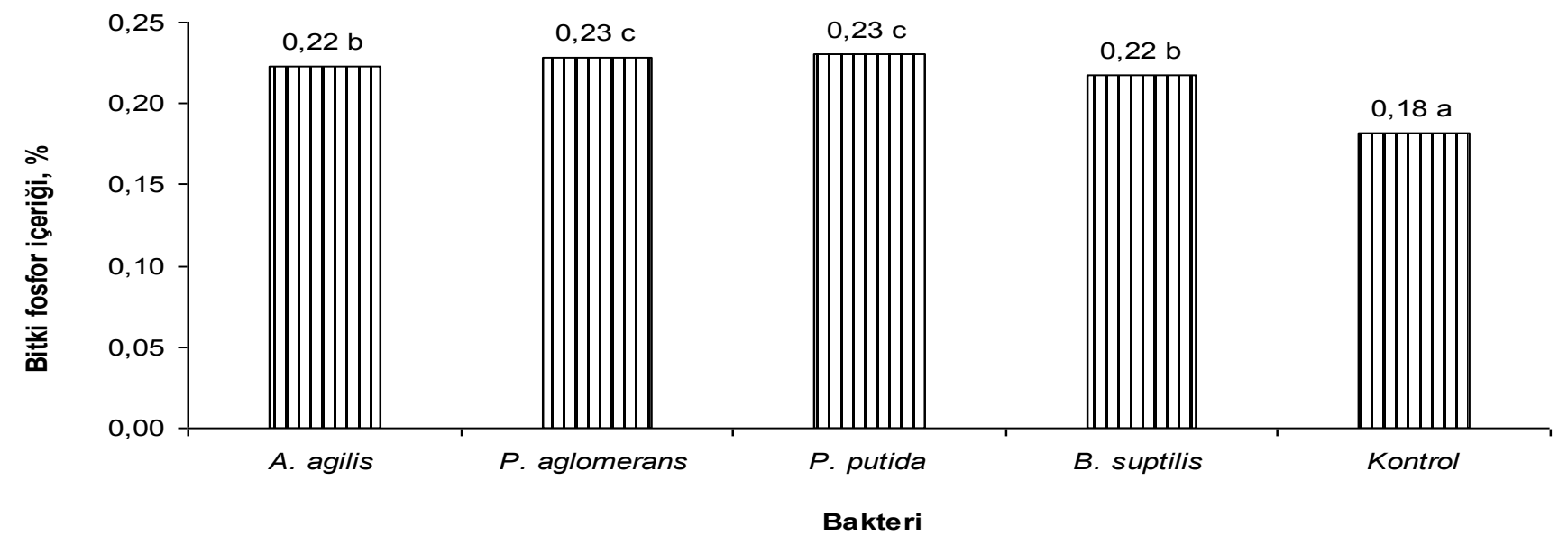

Şekil 7. Farklı bakterilerle aşılanmış buğday ve mısır bitkilerinin fosfor içerikleri

Azotobakterin fosfat çözücü bakterilerle birlikte inokulant olarak uygulandıkları ortamlarda hem bitki verimi üzerinde hem de $\mathrm{N}$ ve $\mathrm{P}$ alımında olumlu sonuçların ortaya çıkmasında etkili olduğu araştırmacılar tarafından vurgulanmıştır (Kundu and Gaur, 1984; Monib ve ark., 1984; Cakmakci ve ark., 2001).

\section{Bitki Potasyum İçeriği}

Bitki potasyum içeriği tüm uygulamalarda \%1 seviyesinde önemli etkiye sahip olmuş bakteri uygulamaları, kontrol grubuna göre daha yüksek bitki potasyum içeriği değerlerini sağlamıştır. Uygulanan bakteriler içerisinde de en yüksek bitki potasyum kapsamının ortaya çıkmasında A. Agilis $(\% 2,26)$ bakterisi etkili olmuş, bunu P. aglomerans (\%2.25), B. suptilis and P. putida (\%2.24) izlemiştir (Şekil 8). Bakteri izolatlarının belli bitki türlerinde daha etkin olması nedeniyle (Khalid ve ark., 2004) farklı çeşitlerde farklı bakterilerin etkin olduğu görülmektedir. Bakteri uygulamalarında; buğdayda 0.08 ile P. putida bakterisi en yüksek değeri verirken, mısırda A. agilis, P. aglomerans bakterileri ve kontrol (0.07) en yüksek değeri vermiş̧lerdir. Benzer bir çalışmada A. chroococcum'un yerli izolatının buğday bitkisinin dane ve sap verimi ile buğday bitkisinin $\mathrm{P}$ ve $\mathrm{K}$ kapsamını önemli oranda $(\mathrm{P}<0.05)$ artırdığı Uygun $(2008)$, mısır ve buğdayda farklı bakteri suşlarının etkin olduğu, bitki gelişimini teşvik eden bakterilerin başarısının bitki tür ve çeşidine bağlı olduğu ifade edilmiştir (Çakmakçı ve ark., 2007; Shakir ve ark., 2012). 


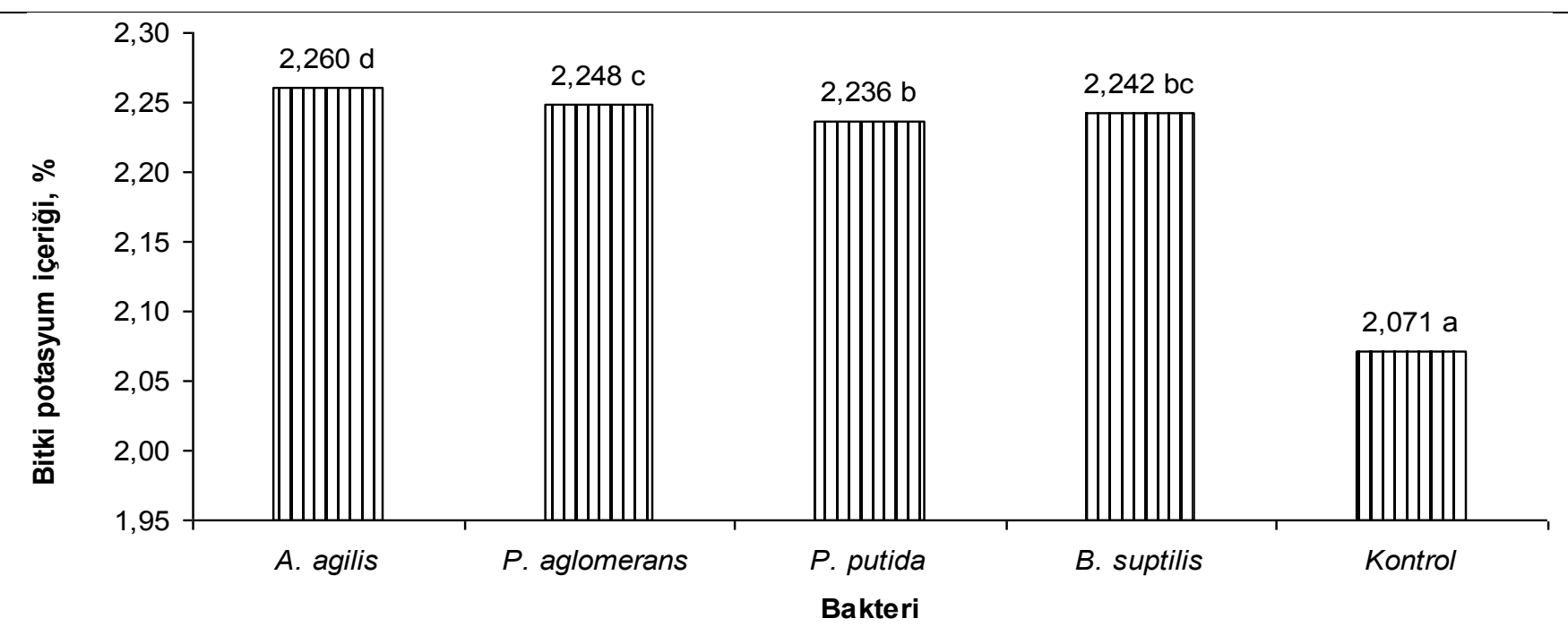

Şekil 8. Farklı bakterilerle aşılanmış buğday ve mısır bitkilerinin potasyum içerikleri

\section{Toprak Reaksiyonu (pH)}

Bakteri uygulamalarında ortalama pH değerleri bakımından, A.agilis, P. aglomerans ve P.putida bakterileri aynı grupta yer almış ve bu bakterilerin inokulasyonu $\mathrm{pH}$ değişiminde birbirlerinden farklılık göstermemiştir. B.suptilis bakterisi ikinci grubu ve kontrolde üçüncü grubu oluşturmuştur. (Şekil 9). Benzer sonuçlar bazı araştırmacılar tarafından da elde edilmiştir (Deubel ve ark., 2000; Canbolat ve ark., 2006). Varyans analizi sonuçlarına göre ortam ve bakteri uygulamaları ile birlikte interaksiyonlar pH değerleri \%1 düzeyinde önemli bulunmuştur. Araştırma sonucuna göre pomza da ve kontrolde pH değerinin hafif alkali çıkmasının tamamen ortamla ilgili olduğu düşünülebilir.

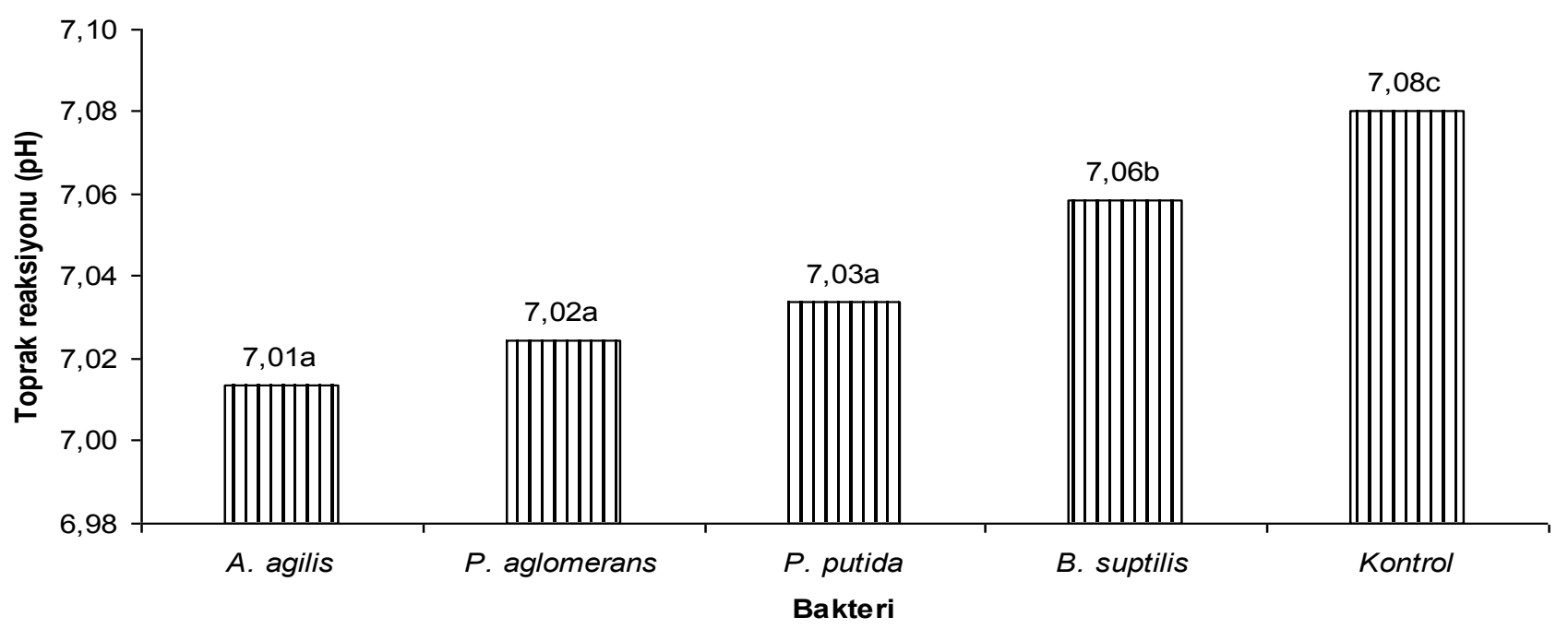

Şekil 9. Bakterilerin yer aldığı örneklerde pH değerleri

\section{Bakteri Sayısı}

Toprakta bulunan makro ve mikroorganizmalar toprak verimliliğini artırarak bitkilerin gelişmesini sağlamakta, bitki gelişimi için gerekli olan C, N, P, S, Fe, Mg gibi elementleri ayrıştırarak ve sentezleyerek bitkilere yarayışlı forma dönüştürmekte ayrıca toprak agregasyonunu sağlayarak toprağın tava gelmesini, yağan yağışların toprağa girişini ve depolanmasını sağlamaktadırlar. Araştırmada hazırlanan yetiştirme ortamlarının bakteri içeriğini oldukça etkilediği görülmüştür. Buğday ve mısır bitkilerinin yetiştirildiği örneklerin ortalama bakteri sayıları, buğdayda $4.5 \times 10^{6} \mathrm{CFU} \mathrm{g}^{-1} \mathrm{k}$. toprak ve misırda $3.5 \times 10^{6} \mathrm{CFU} \mathrm{g}$-1 k. toprak

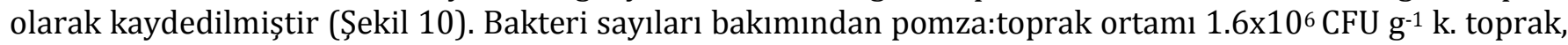
perlit:toprak ortamı $2.4 \times 10^{6} \mathrm{CFU} \mathrm{g}{ }^{-1} \mathrm{k}$. toprak ve torf:toprak ortami $8 \times 10^{6} \mathrm{CFU} \mathrm{g}^{-1} \mathrm{k}$. toprak değerlerine sahip olmuştur. En düşük bakteri sayısı pomza ortamında en yüksek bakteri sayısı da torf ortamında gelişmiştir (Şekil 11). 


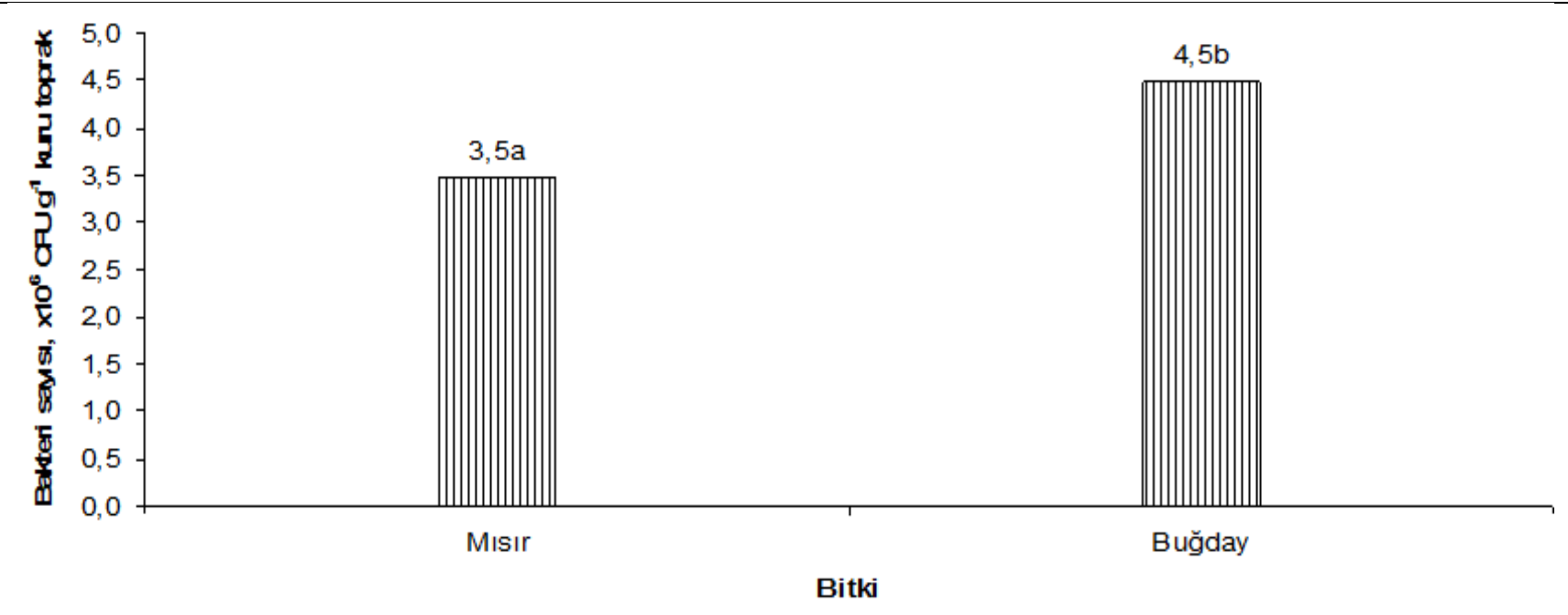

Şekil 10. Buğday ve mısır bitkilerinin yetiştirildiği ortamların ortalama bakteri sayıları, (x106 CFU g-1 k. toprak)

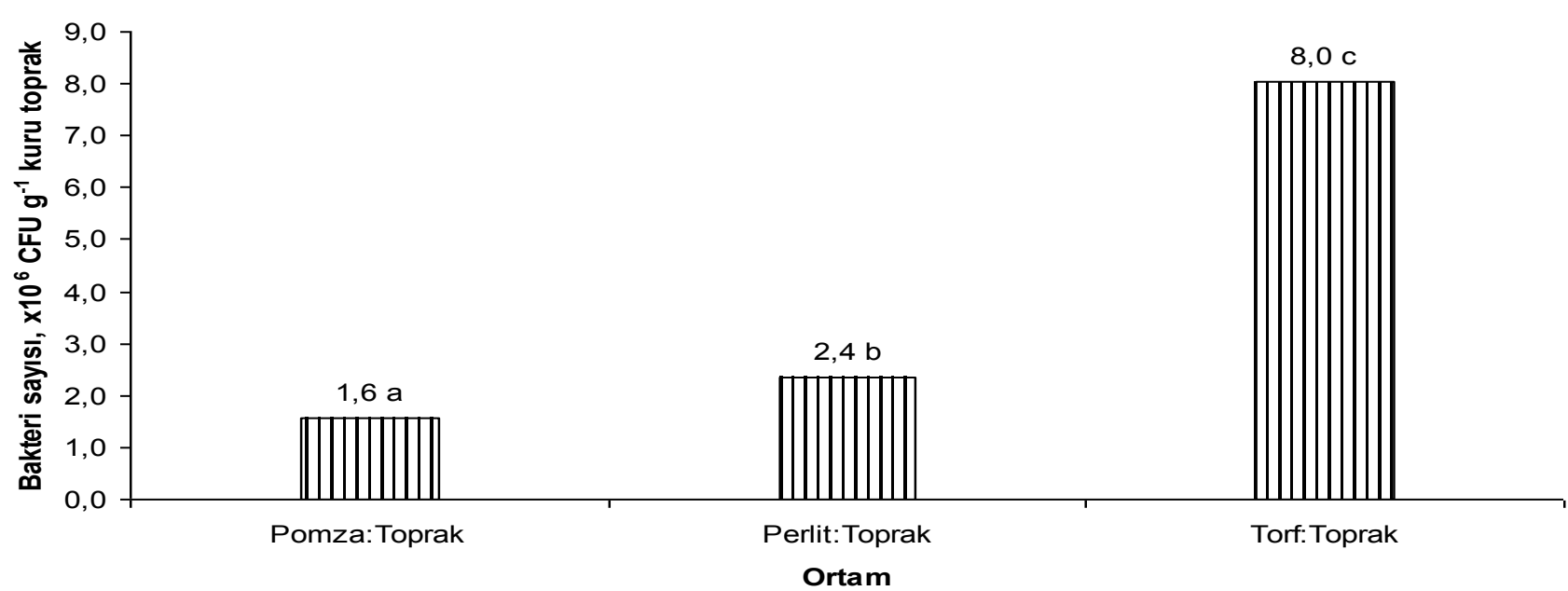

Şekil 11. Ortamlara ait ortalama bakteri sayıları (x106 CFU g-1 k. toprak)

Karışım bakımından, en düşük bakteri sayısı, toprak örneğinin \%100 olarak yer aldı̆̆ı örneklerde $\left(1.2 \times 10^{6}\right.$ CFU g-1 k. toprak) en yüksek değerde materyallerin \%100 olarak yer aldığı örneklerde $\left(8.1 \times 10^{6} \mathrm{CFU} \mathrm{g}^{-1} \mathrm{k}^{2}\right.$ toprak) tespit edilmiştir. Bu sonucu büyük oranda torf materyali etkilemiştir (Şekil 12). Bakteri uygulamaları, kontrol grubuna göre daha yüksek bakteri gelişimini sağlamıştır. Uygulanan bakteriler içerisinde de en fazla bakteri gelişimi P. aglomerans $\left(5.5 \times 10^{6} \mathrm{CFU} \mathrm{g}^{-1} \mathrm{k}\right.$. toprak) ve en düşük bakteri gelişimi de B. suptilis uygulamasında (3.1 x106 $\mathrm{CFU} \mathrm{g}^{-1} \mathrm{k}$. toprak) kaydedilmiştir (Şekil 13). Toprağa inorganik ve organik materyallerin karıştırılması ile bakteri sayılarının artabileceği birçok çalışmada kaydedilmiştir (Özkan, 1986; Astaraei ve ark., 2008; Shariati ve ark., 2013).

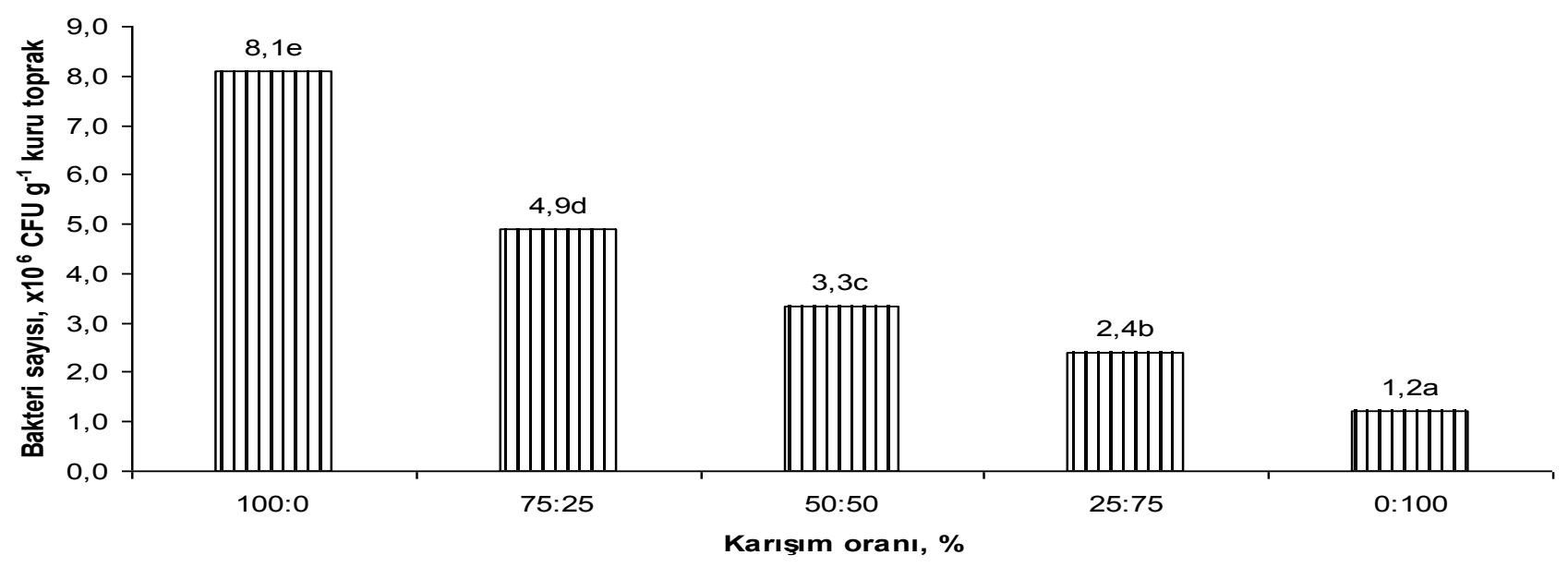

Şekil 12. Karışım oranlarına göre ortalama bakteri sayıları (x106 CFU g-1 k. toprak) 


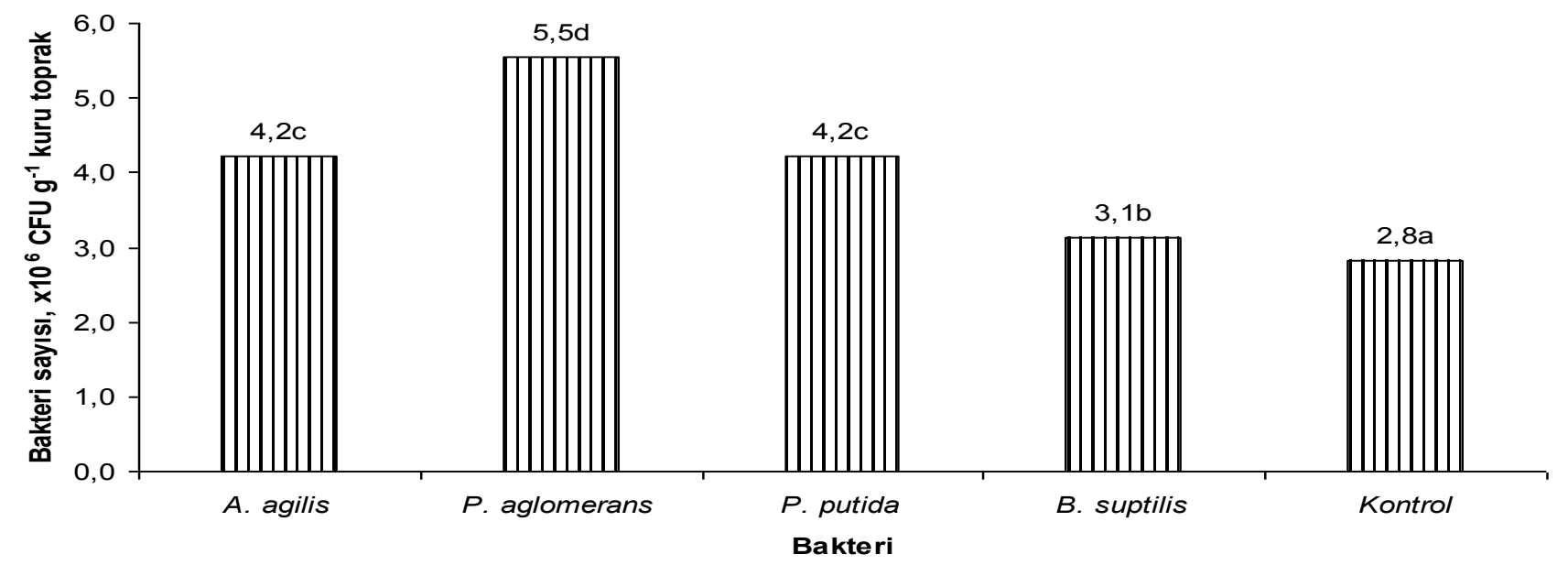

Şekil 13. Bakteri uygulamalarına göre ortalama bakteri sayıları (x106 CFU g-1 k. toprak)

\section{Sonuç}

Sonuç olarak saf pomza materyalinin kuru kök ve gövde ağırlı̆̆ değerlerini, saf torf materyalinin ise bakteri sayısı değerlerini artırdı̆̆ı materyal toprak karışımlarında toprak oranı arttığı zaman kuru kök ve gövde ağırlı̆̆ı, bitki azot, fosfor ve potasyum değerlerinin arttı̆̆ı, bakteri sayısı değerlerinin ise azaldığı belirlenmiştir. Torf ortamında bakteri sayısındaki artma nedeninin torf materyalinde organik madde miktarının ve nem oranının fazla olmasından kaynaklandığı düşünülmektedir. Denemede P.aglomerans ve A.agilis suşlarının daha etkin olduğu, kullanılan materyallerin saf ya da toprakla karışım olarak sera ve laboratuvar da kullanılabileceği paralelinde tarla denemelerinin de yapılmasının bakteri kullanımını artırabileceği ve etkin kullanımın sağlanmasında önemli rol oynayabileceği düşünülmektedir.

\section{Kaynaklar}

AOAC, 1990. Official Methods of Analysis of the Association of Official Analytical Chemists. In: Helrich, K (Ed.), Washington, DC.

Astaraei AR, Sanaeinejad SH, Mir. Hosseini MP, Ghoemi M, Keshavarzi A, 2008. Evaluatıon of vegatation cover and soil indices for soline land classification in Neyshabour region using ETM+Landsat. International symposium on gooinformatics for spatial infrastructure development in eart and allied sciences.778.

Bangash N, Khalid A, Mahmood T, Tariq Siddique M, 2013. Screening rhizbacteria containing acc-deaminase for growth promoting of wheat under water stress. Pakistan Journal of Botany 45, 91-96.

Baset Mia MA, Shamsuddin ZH, Wahab Z, Marziah M, 2010. Effect of plant growth promoting rhizobacterial (PGPR) inoculation of tissue-cultures Musa plantlets under nitrogen-free hydroponics condition. Australian Journal of Crop Science, 4 (2): 85-90.

Beşiroğlu A, 2007. Magnezyumun sera koşullarında farklı büyüme ortamlarında yetiştirilen domatesin gelişmesi, magnezyumun alımı ve dağılımına etkisi. Doktora Tezi, Ankara Üniversitesi Fen Bilimleri Enstitüsü Toprak Anabilim Dall, Ankara.

Canbolat M, Bilen S, Cakmakci R, Sahin F, Aydin A, 2006. Effect of plant growth promoting rhizobacteria and soil compaction on barley seedling growth, nutrient uptake, soil properties and rhizosphere microflora. Biology and Fertility of Soils 42, 350-357.

Cakmakci R, Kantar F, Sahin F, 2001. Effect of N2-fixing bacterial inoculations on yield of sugar beet and barley. Journal of Plant Nutrition and Soil Science 164, 527-531.

Çakmakçı R, 2005a. Bitki gelişimini teşvik eden rizobakterilerin tarımda kullanımı. Atatürk Üniversitesi Ziraat Fakültesi Dergisi 36 (1), 97-107.

Çakmakçı R., 2005b. Bitki gelişiminde fosfat çözücü bakterilerin önemi. Selçuk Üniv. Ziraat Fakültesi Dergisi 35, 93-108.

Cakmakci R, Donmez F, Aydın A, Sahin F, 2006. Growth promotion of plants by plant growth-promoting rhizobacteria under greenhouse and two different field soil conditions. Soil Biology and Biochemistry 38, 1482-1487.

Cakmakci R, Donmez MF, Erdoğan UG, 2007. The effect of plant growth promoting rhizobacteria on barley seedling growth, nutrient uptake, some soil properties, and bacterial counts. Turkish Journal of Agriculture and Forestry 31, 189-199.

Chen Y, MeiR, Lu S, Liu L, Kloepper JW, 1996. The use of Yield Increasing Bacteria (YIB) as Plant Growth Promoting Rhizobacteria in Chinese Agriculture. Management of Soil Borne Diseases, R.S. Utkhede and V.K. Gupta ed. Kalyani Publishers, Ludhiada. New Delhi. 
Clark FE, 1965. Agar-Plate Metod for Total Microbial Count. Methods of Soil Analiysis. Chemical and Mikrobiological Properties. C. A. Black, D.D. Evans, J. L. White, L, E. Ensminger and F.E. Clark (ed) byAmer. Soc.Agron. Inc, Madison,Winsconsin USA Agron. 9, Part 2, 1460-1466.

Deubel A, Gransee A, Merbach W, 2000. Transformation of organic rhizodepositions by rhizosphere bacteria and its influence on the availability of tertiary calcium phosphate. Journal of Plant Nutrition and Soil Science 163, 387392.

Dowdy S, Weardin S, 1983. Statistics for Research. John Wiley and Sons Inc. NewYork, USA.

Garten CT, Van Miegroet H, 1994. Relationship between site nitrogen dynamics and natural 15N abundance in plant foliage from the Great Smoky Mountains National Park. Canadian Journal of Forest Research 24: 1636-1645.

Göçmen A, 2005. Pomza ve perlitin havuç bitkisinin (Daucus carota) gelişimine etkisi. Selçuk Üniversitesi Fen Bilimleri Enstitüsü, Toprak Anabilim Dalı Yüksek Lisans Tezi. Konya.

Jagnow G, 1987. Inoculation of cereal crops and forage grasses with nitrogen-fixing rhizosphere bacteria: a possible cause of success and failure with regard to yield response - a review. Z. Pflanzenernaehr. Dueng. Bodenkde, 150, 361-368.

Kacar B, 1996. Bitki Fizyolojisi. Ankara Üniversitesi Ziraat Fakültesi, Toprak Bölümü. Yayın no: 1447, s:427.

Kadıoğlu B, Canbolat MY, 2018. The Effects of Different Growıng Medıums on The Root Development of Wheat. 2nd international Conference on Triticalae and Wheat Biology, Breeding and Pruduction. June 25-28, 2018. Erzurum/Turkey.

Karaman M, 1993. Bitki yetistirme ortamı olarak pomza tasının farklı azot dozlarında mısır bitkisinin gelismesine etkisi. Gazi Osman Pasa Üniv. Fen Bilimleri Enstitüsü Yüksek Lisans Tezi.

Khalid A, Arshad M, Zahir ZA, 2004a. Screening plant growth promoting rhizobacteria for improving growth and yield of wheat. Journal of Applied Microbiology, 96, 473-480.

Kloepper JW, Lifshitz R. and Zablotowicz R.M, 1989. Free living bacterial inocula for enhancing crop productivity. Trends in Biotechnology, 7, 39- 44.

Knoepp JD, Swank WT, 1998. Rates of nitrogen mineralization across an elevation and vegetation gradient in the southern Appalachians. Plant and Soil 204:235-241.

Kundu BS, Gaur AC, 1984. Rice response to inoculation with N2-fixing and P-solubilizing microorganisms. Plant and Soil, 79, 227-234.

Lucy M, Reed E, Glick BR, 2004. Aplications of free living plant grovth-promoting rhizobacteria. Antonie van Leeuwenhoek, International Journal of General and Molecular Microbiology, 86, 1-25.

Özkan CF, 1986. Topraklara perlit uygulamasının azotobakterilerin aktivitesi ve biyolojik azot fiksasyonu üzerine etkileri. Ege Üniversitesi Fen Bilimleri Enstitüsü Toprak Anabilim Dalı, Yüksek Lisans Tezi, İzmir.

Mc Lean E0, 1982. Soil pH and Lime Requirement. Methods of Soil Analysis Part 2. Chemical and Microbiological Properties Second Edition. Agronomy. No: 9 Part 2., 199-224.

Mertens D, 2005. AOAC Official Method 975.03. Metal in Plants and Pet Foods. Official Methods of Analysis, 18th ed. Horwitz, W. and G.W. Latimer, (Eds). Chapter 3, pp 3-4, Gaitherburg, Maryland 20877-2417, USA.

Monib M, Hosny I, Besada YB, 1984. Seed inoculation of castor oil plant (Ricinus communis) and effect on nutrient uptake. Soil Biology and Conservation of the Biosphere : Soil Science, 2, 723-732.

Ping L, Boland W, 2004. Signals from the underground: bacterial volatiles promote growth in Arabidopsis. Trends in Plant Science, 9 (6), 263-266.

Shakir MA, Bano A, Arshad M, 2012. Rhizosphere bacteria containing ACC deaminase conferred drought tolerance in wheat grown under semi-arid climate. Soil \& Environment, 31 (1):108-112.

Shariati L, Validi M, Tabatabaiefar MA, Karimi A, Nafisi MR, 2013. Comparısıon of real-time PCR with disk diffusion agar screen and E-test methods for detection of methicillin-resistand Stophylococus ourcus. Current Microbiology 61(6)-520-4.

Sahin F, Cakmakci R, Kantar F, 2004. Sugar beet and barley yields in relation to inoculation with N2-fixing and phosphate solubilizing bacteria. Plant and Soil, 265, 123-129.

TÜİK 2019. http://www.tuik.gov.tr/PreTablo.do?alt_id=1001

Türk M, Bayram G, Budaklı E, Çelik N, 2003. Farklı Yetiştirme Ortamlarının Arpa Bitkisinin Kök ve Gövde Gelişimi Üzerine Etkileri. Türkiye 5. Tarla Bitkileri Kongresi, 2, 26-30, Diyarbakır.

Uygun B, 2008. Azotobacter spp. ile aşılamanın buğday bitkisinin verim ve besin elementi kapsamına etkisinin saptanması ve biyolojik gübre üretiminde uygun taşıyıcı materyalin belirlenmesi. Yüksek Lisans Tezi, Ondokuz Mayıs Üniversitesi, Fen Bilimleri Enstitüsü, Toprak Anabilim Dalı, Samsun.

Vessey JK, 2003, Plant growth promoting rhizobacteria as biofertilizers, Plant and Soil, 255, 571-586.

Wollum AG II, 1982. Cultural Methods for Soil Microorganizms Methods of Soil Analiysis. Chemical and Microbiological Properties. AL Page (ed.) Amer. Soc. Agron., Inc., Madison, Wisconsin USA. Agron 9. Part 2. Second Edition. P. 781-801. 